\title{
Detection of Severe Acute Respiratory Syndrome Coronavirus 2 RNA in Blood Donations
}

\author{
Usman Waheed ${ }^{1} \quad$ Akhlaaq Wazeer ${ }^{2} \quad$ Noore Saba $^{3}$ \\ 1'Islamabad Blood Transfusion Authority, Ministry of National Health \\ Services, Islamabad, Pakistan \\ 2Department of Pathology and Transfusion Medicine, Divisional \\ Headquarters Teaching Hospital, Mirpur, Azad Jammu and \\ Kashmir, Pakistan \\ ${ }^{3}$ Peshawar Regional Blood Centre, Department of Health, Khyber \\ Pakhtunkhwa, Pakistan
}

J Lab Physicians:2020;12:163-164

The first case of Coronavirus disease 2019 (COVID-19) caused by severe acute respiratory coronavirus 2 (SARS-CoV-2) was reported from the Hubei province of China in December 2019. ${ }^{1}$ It has now developed into a pandemic, ${ }^{2}$ accelerating on a scale never witnessed from any other viral agent with pandemic capability. As of June 2, 2020, the disease has affected 212 countries, infecting over 6.2 million people with 0.38 million deaths. ${ }^{3}$ The disease stretched to Pakistan later than many other countries, as the first case was recorded on February 26, 2020, and now, the number of cases is more than 76,000 (as of June 2, 2020). ${ }^{3}$

This unprecedented scenario is adversely affecting the health systems across the globe. ${ }^{4}$ This includes overwhelming the blood transfusion services with reports of shortfalls in the number of blood units collected. ${ }^{5}$ Since the outbreak of COVID-19, there were concerns about the potential risk of transmission through the transfusion of blood and blood components. The SARS-CoV-2 belongs to the respiratory group of viruses that are not known to be transmitted by blood transfusion, and there have been no reported cases so far. However, during the early phase of the epidemic, the RNA of SARS-CoV-2 was detected in plasma, ${ }^{6}$ and later two preliminary studies from Wuhan Blood Center (China) ${ }^{7}$ and Korean Red Cross (South Korea) ${ }^{8}$ reported viral RNA detection in blood donors. Therefore, the possibility of transmission by blood transfusion is worthy of consideration.

This prompted us to conduct a pilot study in order to screen blood donations collected in our blood bank at the divisional headquarters teaching hospital, Mirpur, Azad Jammu and Kashmir, Pakistan. To mitigate the theoretical risk of acquiring SARS-CoV-2 following transfusion, we retrospectively screened whole blood donations collected during the 4-week period starting from March 16 to April 13, 2020. A total of 690 tests were performed on samples (were in storage at $2-8^{\circ} \mathrm{C}$ ) for the presence of viral RNA through real-time RT-PCR (reverse transcription-polymerase chain reaction). A total of $140 \mu \mathrm{L}$ of donor's sample was subjected
Address for correspondence Usman Waheed, PhD, Islamabad Blood Transfusion Authority, Ministry of National Health Services, Islamabad, Pakistan (e-mail: drusman.waheed1@gmail.com).

to RNA extraction using QIAamp Viral RNA Mini Kit (Qiagen, Hilden, Germany), following the manufacture's instruction. Real-time, one-step RT-PCR was performed, targeting the ORF1 ab and $\mathrm{N}$ genes of SARS-CoV-2. The kit (DAAN Gene Co., Ltd., Guangzhou, China) consists of an internal control system where Cy5 is labeled on internal control gene probe and used to check the processes of sample collection, RNA, and PCR amplification, thus reducing false-negative results.

We identified two donor samples positive for SARS-CoV-2. The whole blood units had been separated into red cell concentrates (RCC) and fresh frozen plasma (FFP) but not platelet concentrates. Both FFPs were in the blood bank's inventory, while the RCCs were already transfused to two patients. Both patients, discharged from the hospital, were traced and called. They had not developed any posttransfusion symptoms related to COVID-19. Fresh nasopharyngeal samples were drawn from both recipients of RCC and were found to be negative for viral RNA. The two FFPs in the blood bank stock were retested to see the viral RNA stability and found to be positive, indicating the stability of RNA at $-40^{\circ} \mathrm{C}$ in plasma.

Both reactive donors were followed up through telephone; they had remained asymptomatic and were advised to limit contact and quarantine at home. This characteristic feature of COVID-19 to remain asymptomatic in the majority of infected individuals ${ }^{9}$ has a huge impact on blood donor recruitment, making it challenging to recruit donors.

Although the recipients of SARS-CoV-2 positive RCCs tested negative and had no symptoms, the potential risk may not be disregarded, and more time will be required to conclude the level of blood safety interventions. Meanwhile, the blood bank has implemented the standard protocols to mitigate the theoretical risk of SARS-CoV-2 transmission through blood and blood components transfusions. This includes monitoring the temperature of blood donors, hand hygiene, and increasing space between donation couches. The screening questionnaire of blood donors has been revised and additional questions incorporated, such as asking about specific symptoms in donor 
or family members and a history of traveling to cities with reports of local transmission. The blood bank staff has been directed to remain vigilant and in close contact with donors and the Central COVID-19 Laboratory. Besides, the blood bank has also requested the Central COVID-19 Laboratory to provide a list of all individuals tested positive in district Mirpur and adjoining regions. These donors will be temporarily deferred from donating blood in case they come up for donations in the near future. All these steps are expected to ensure safer transfusion of blood and blood components at present and in the postpandemic era also.

One limitation of our study is that RT-PCR positivity does not necessarily imply the presence of viable virus in the blood and blood components, and viral culture was not performed to confirm this concerning possibility.

Additional broad-based research is needed to further validate the survival of viral RNA in blood and blood components and its infectivity with respect to recipients.

\section{Conflicts of Interest}

None declared.

\section{Acknowledgments}

Dr. Farooq Ahmed Noor, Medical Superintendent, Divisional Headquarters Teaching Hospital, Mirpur, Azad Jammu and Kashmir, Pakistan.

\section{References}

1 Zhou P, Yang XL, Wang XG, et al. A pneumonia outbreak associated with a new coronavirus of probable bat origin. Nature 2020;579(7798):270-273

2 Cucinotta D, Vanelli M. WHO declares COVID-19 a pandemic. Acta Biomed 2020;91(1):157-160

3 World Health Organization. Coronavirus disease (COVID-19) outbreak situation. Available at: https://www.who.int/emergencies/diseases/novel-coronavirus-2019/situation-reports/. Accessed June 2, 2020

4 Fauci AS, Lane HC, Redfield RR. Covid-19 - navigating the uncharted. N Engl J Med 2020;382(13):1268-1269

5 Cai X, Ren M, Chen F, Li L, Lei H, Wang X. Blood transfusion during the COVID-19 outbreak. Blood Transfus 2020;18(2):79-82

6 Huang C, Wang Y, Li X, et al. Clinical features of patients infected with 2019 novel coronavirus in Wuhan, China. Lancet 2020;395(10223):497-506

7 Chang L, Zhao L, Gong H, Wang L, Wang L. Severe acute respiratory syndrome coronavirus 2 RNA detected in blood donations. Emerg Infect Dis 2020;(e-pub ahead of print). doi: 10.3201/eid2607.200839

8 Kwon SY, Kim EJ, Jung YS, Jang JS, Cho NS. Post-donation COVID-19 identification in blood donors. Vox Sang 2020; (e-pub ahead of print). doi: 10.1111/vox.12925

9 Chan JF-W, Yuan S, Kok K-H, et al. A familial cluster of pneumonia associated with the 2019 novel coronavirus indicating person-to-person transmission: a study of a family cluster. Lancet 2020;395(10223):514-523 